\section{Organic and Inorganic Compounds in limestone Weathering Crusts from Cathedrals in Southem and Westem Europe}

\author{
BART O. FOBE, GRETA J. VLEUGELS, \\ EDDY J. ROEKENS, AND \\ RENÉ E. VAN GRIEKEN* \\ Department of Chemistry, University of Antwerp (ULA), \\ B-2610 Antwerp-Wilrijk, Belgium
}

BERNARDO HERMOSIN, JOSÉ JULIO ORTEGA-CALVO, ANGEL SANCHEZ DEL JUNCO, AND CESAREO SAIZ-JIMENEZ.

Instituto de Recursos Naturales y Agrobiologia, Apartado 1052, E-41080 Sevilla, Spain

Limestone and weathering crusts have been studied at the major cathedrals of Sevilla, in southwestern Spain, and Mechelen, in northern Belgium. These cities have very different climatic and environmental conditions. The deterioration characteristics of the limestone in both localities have been compared. Detailed petrographical characterization was carried out for the different building stones, including restoration materials. The bulk and trace inorganic composition of the stones and crusts was assessed, and the leachable ions were analyzed, while elemental concentration profiles with depth were studied with electron microprobe analysis. The organic compounds in the black weathering crusts have also been studied and compared. In the different types of limestone, the deterioration is largely influenced by the petrographic characteristics of the stone. Gypsum crusts from Mechelen and Sevilla show variable textures, even on the same stone types. Sulfatation of calcite provides $\mathrm{Ca}$ for the gypsum crusts. Except for a part of the Sr and Fe fractions in the crust, all other elements may be of external origin. Concentrations of the various elements are more or less comparable in crusts from Mechelen and Sevilla. External inorganic particles consist of fly ash, quartz, clay, and glauconite. Most of the organic material appeared to be of anthropogenic origin, due to combustion processes, while a minor fraction originated from cuticular waxes of higher plants.

\section{Introduction}

Sevilla and Mechelen are cities located in very different climatic regions in Europe. Sevilla (700 000 inhabitants), in Andalucia, southwestern Spain (Figure 1), is one of Europe's southernmost cities. This part of the Iberian peninsula is among the regions with the highest average temperatures in Europe, $10.7^{\circ} \mathrm{C}$ in January (average daily maxima and minima of 16 and $5^{\circ} \mathrm{C}$, respectively) and 26.8 ${ }^{\circ} \mathrm{C}$ in July (average daily maxima and minima of 35 and 19 ${ }^{\circ} \mathrm{C}$, respectively), with an insolation of $2750 \mathrm{~h} /$ year. It rains $620 \mathrm{~mm} /$ year in Sevilla, mostly in winter (the average rainfall in January and July is 66 and $0 \mathrm{~mm}$, respectively), and the average relative humidity is only $59 \%$. The climate in Mechelen (80 000 inhabitants) in Flanders, northern Belgium (Figure 1), is much colder, with an average temperature of $2^{\circ} \mathrm{C}$ in January (average daily maxima and minima of 4 and $-1{ }^{\circ} \mathrm{C}$, respectively) and $18^{\circ} \mathrm{C}$ in July (average daily maxima and minima of 22 and $12{ }^{\circ} \mathrm{C}$, respectively), and it is also marked by a high relative humidity and by an average precipitation of $850 \mathrm{~mm} /$ year, which is rather evenly spread over the year. Both cities have limestone cathedrals of very high historical value, which are seriously threatened presently by air pollution.

The first stone of the cathedral of Sevilla was laid in 1402, and the construction lasted until 1927, when the Conception Gate was finished. Through the 15th century, stones from the quarries of the Cadiz and Sevilla provinces (Jerez, Puerto de Santa Maria, Sanlucar de Barrameda, Alcala de Guadaira) and Portugal were used. During the 16th century, the origin of the stones was even more diverse (1). The most abundant stone type is a yellowish fossiliferous calcarenitic limestone of Miocene age, whereas white oölithic and micritic limestones were used during the 19th20th century construction. The mineralogical composition of the calcarenite is $45-97 \%$ calcite and $3-55 \%$ quartz, with traces of phyllosilicates; the micritic limestone is $95 \%$ calcite and 5\% quartz, while the oölithic limestone is $100 \%$ calcite (2). The original yellowish or whitish colors turned gray or black due to air pollution exposure during the last century. The mean atmospheric $\mathrm{SO}_{2}$ and particulate matter levels in $1976-1980$ were 87 and $174 \mu \mathrm{g} / \mathrm{m}^{3}$, respectively, at a station near the cathedral. In 1980-1985, the mean $\mathrm{SO}_{2}$ level was $47 \mu \mathrm{g} / \mathrm{m}^{3}$. After 1985 , the station was discontinued. Today, higher levels are presumed because the cathedral neighborhood is characterized by dense traffic, areas of car parking, and narrow sheltered streets, a typical configuration of historic centers in old Andalusian cities. High-rising damp levels have been observed on the cathedral walls (2). These deteriorating factors are enhanced by the softness of the high-porosity limestone. The most important deterioration is caused by sulfatation of calcite and dissolution of calcitic cement. Technical characteristics of the building materials used in the Sevilla cathedral have been reported by Esbert et al. (3).

The city of Mechelen is located on the industrial axis between the major cities of Antwerp and Brussels. Refineries, electrical power plants, and non-ferrous industries make this area the most important emitter of industrial $\mathrm{SO}_{2}$ and $\mathrm{NO}_{\mathrm{x}}$ in Belgium. Like many ancient buildings in northern Belgium, the 15th century St. Rombouts cathedral was built with materials of local origin: Balegem and 


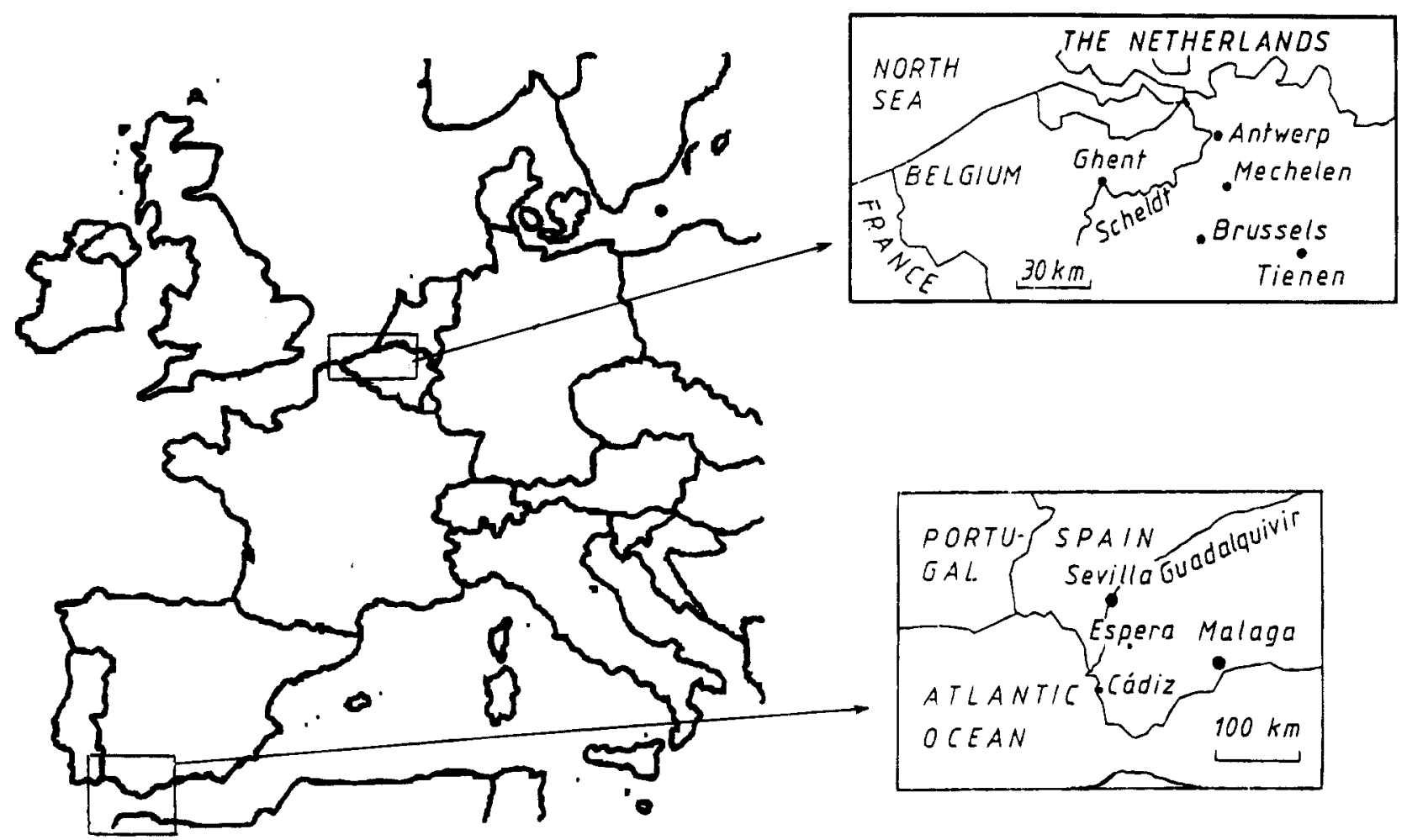

FIGURE 1. Location of Mechelen, Sevilla, and the provenance areas of the building stones of the cathedrals.

Diegem limestone, quarried in the region between Ghent and Tienen and particularly near Brussels. During restoration campaigns at the beginning of this century and about 1974, Balegem stone was replaced by Euville and Massangis limestone, respectively, both types from France. A few years ago, the characteristics and inorganic composition of the weathering crusts on the original limestone were studied to some extent $(4,5)$.

In the present study, the deterioration characteristics of limestone in both localities are compared in much detail, in an effort to elucidate further the decay mechanisms, to identify the pollution types involved, and hence to help in policy-making for regulations to reduce the deterioration rate. The results pertain to the different deterioration mechanisms of limestone in different environmental and climatic conditions.

\section{Experimental Section}

Samples. Samples from the Sevilla cathedral were taken from the eastern side (SEV1), from the major nave (SEV2, SEV3, and SEV4), and from the southern side (SEV5a and SEV5b). All the samples are yellowish calcarenitic limestones. Most of the stones are brittle and covered by a thin but hard black crust.

For the Mechelen cathedral, the Balegem stone samples studied (MECH1 and MECH2) were taken at the $33 \mathrm{~m}$ high balcony. Euville stone (MECH3 and MECH4) comes from sculptured blocks, removed during the recent restoration campaign of the tower (between 33 and $50 \mathrm{~m}$ ). All the samples are covered by thick, irregular black crusts. At the $95 \mathrm{~m}$ high balcony of the Mechelen cathedral, samples of Massangis stone were taken at each side of the tower.

Petrography and Electron-Probe Microanalysis. Stone and crust samples were studied in thin sections treated with K-ferricyanid and Alizarine red S, in order to check for the presence and distribution of ferroan calcite (6). Before staining, electron probe X-ray microanalysis (EPXMA) was performed. In each thin section, 3-5 profile lines, with 20 points each, were analyzed with a JEOL JXA 733 superprobe, operated at $20 \mathrm{kV}$ and $1 \mathrm{nA}$.

Inorganic Analysis. Elemental concentrations in crusts and stones were directly obtained by neutron activation analysis (NAA) and X-ray fluorescence (XRF). The irradiations for NAA were carried out in the research reactor Thetis of the University of Ghent. The emitted $\gamma$-rays were measured using a $\mathrm{Ge}(\mathrm{Li})$ detector and a Ge low-energy photon detector. NAA allows very low detection limits to be obtained for some trace and rare elements, but this method cannot be applied for some important elements. The concentrations of additional elements were obtained by energy-dispersive XRF. The XRF setup was a Tracor TN-5000 unit with filtered polychromatic Rh tube excitation.

Anion concentrations were measured with a Dionex $4000 \mathrm{i}$ ion chromatograph and cations by means of atomic absorption or atomic emission spectrometry (using a Perkin-Elmer 3030 spectrometer) after crust samples had been crushed in a mortar and leached in bidistilled water for $20 \mathrm{~min}$. A similar procedure was carried out in $0.1 \mathrm{~N}$ $\mathrm{HCl}$, in order to dissolve oxalate salts.

The insoluble crust material remaining after the treatment with $\mathrm{HCl}$ was collected on a $0.2 \mu \mathrm{m}$ Millipore filter. The elemental composition of these particles was measured automatically by scanning the filter with EPXMA; this automated procedure for particle recognition, sizing, and analysis has been described in detail (7). The procedure analyzes hundreds of individual particles per filter in a short period and yields size information and concentration data for a dozen elements in every particle. This huge amount of generated data is afterward processed by multivariate analysis techniques.

Organic Analysis. Organic compounds in the crusts were obtained by solvent extraction and analyzed in a gas chromatography/mass spectrometry system (GC/MS). Briefly, black crusts were carefully removed from the 


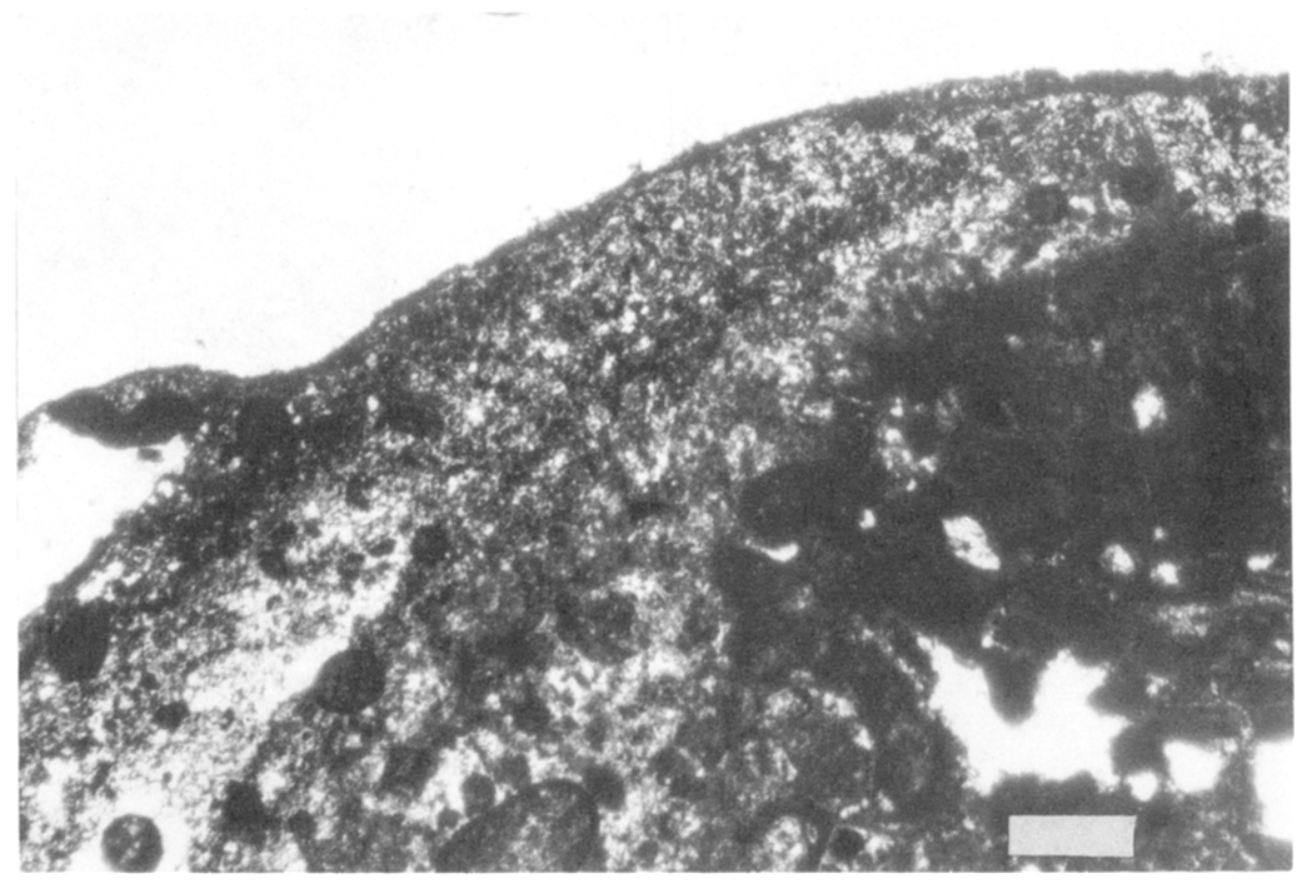

FIGURE 2. Microphotograph (cross-polarized light) of sample SEV4 from the Sevilla cathedral. The dark zone in the lower right is the unweathered limestone. It is covered by a gypsum crust, consisting of several layers, each one bordered by a thin dark rim of soot, dust, and iron oxides, representing former surfaces of prolonged exposure. The actual surface is also bordered by such a dark rim, locally overlaid by a new generation of gypsum (the bump on the left). To the the right, the crust gets thinner and the dark rims merge. Scale bar, $100 \mu \mathrm{m}$.

limestone and ground in an agate mortar. Twenty gram samples were extracted in a Soxhlet apparatus with toluene $(200 \mathrm{~mL}, 8 \mathrm{~h})$ and methanol $(200 \mathrm{~mL}, 8 \mathrm{~h})$. Both extracts were mixed and evaporated under vacuum at low temperature (below $40^{\circ} \mathrm{C}$ ) and redissolved in diethyl ether. Acidic compounds were derivatized by addition of an excess of diazomethane solution in ether; consequently, carboxylic groups were converted into methyl esters. An aliquot of the extract was injected into a GC/MS system. Methods and analytical conditions have been thoroughly described elsewhere (8). Separation and identification of the compounds was achieved using a fused-silica capillary column $(25 \mathrm{~m} \times 0.32 \mathrm{~mm}$ i.d.) coated with CP Sil 5 . The temperature program was from $0(1 \mathrm{~min})$ to $320^{\circ} \mathrm{C}(15 \mathrm{~min})$ at a rate of $3^{\circ} \mathrm{C} \mathrm{min}{ }^{-1}$. The analysis was performed with an HP 5890 GC unit, interfaced with a VG 70-250 SE double focusing mass spectrometer operating under the following conditions: ionization energy, $70 \mathrm{eV}$; mass range, $\mathrm{m} / \mathrm{z} 50-800$; cycle time, $2 \mathrm{~s}$. Alternatively, the extract was deposited onto a Curie-point ferromagnetic wire $\left(358^{\circ} \mathrm{C}\right)$, the solvent evaporated, and the wire inserted into a pyrolysis unit mounted in the injection block of the GC/MS system described above, under identical programming. This allows the compounds to be evaporated by heating at $358{ }^{\circ} \mathrm{C}$ for $10 \mathrm{~s}$, avoiding solvent interferences.

\section{Results}

Petrography. Crusts from the Sevilla Cathedral. The limestone samples show a packstone texture, consisting of fossils and a small amount of quartz in a fine-grained micritic to microsparitic matrix. Most of the fossils are calcareous algae and bryozoans, bivalve shell debris, and other sand-sized calcite particles. Carbonate staining tests indicate that the fossils and the cement consist of low-iron and low-magnesium calcite. The amount of fossils varies; sample SEV4 is particularly rich. Sample SEV3, on the other hand, contains the most quartz.
The contact between the sandstone and its black crust is sharp. Usually, the black crust is limited to a thin isotropic coverlayer (50-60 $\mu \mathrm{m}$ thick). A well-developed crust is observed only in sample SEV4 (Figure 2). The thickness varies between 0.5 and $2.5 \mathrm{~mm}$. The inner part consists of brown, fine-grained, nearly isotropic but rather clean gypsum. It is overlaid by an Fe-rich layer. This succession of clean and dirty crust may be as thick as $1 \mathrm{~mm}$. It passes laterally into an Fe-rich coating upon the stone surface, only a few tens of micrometers thick. The next zone, the thickest one, is formed by fine-grained gypsum, very rich in black particles and containing scattered silt-sized quartz grains. Under crossed polarizers, the crust material looks nearly isotropic. The outer border is fringed by a thin opaque cover, usually forming the outer surface of the crust. Within the crust layer, similar thin black rims are observed. Locally, this sequence is overlaid by a third generation of gypsum, somewhat coarser grained and looking less isotropic. Its outer limit is also an opaque rim. The black rims within the crust probably mark phases of a long exposure period to the atmosphere, after a crust layer was formed. In sample SEV4, three main depositional sequences are observed (Figure 2). The layers appear to have been deposited upon each other, without dissolution of former sequences.

Gypsum is also found in isolated pockets in the stone itself. It occurs as small lenticular crystals $(10 \mu \mathrm{m})$ within the sparite cement, which is broken up into individual crystals. Such gypsum pockets are in sharp contact with the surface crust. Small patches of gypsum also occur in chambers of fossils connected with the crust.

Crusts from the Mechelen Cathedral. Balegem Stone. The original Balegem stone of the Mechelen cathedral is a sandy limestone, consisting of about $55 \%$ calcite, cementing quartz, glauconite grains and fossils. The stone is covered by a black gypsum crust, consisting mostly of 


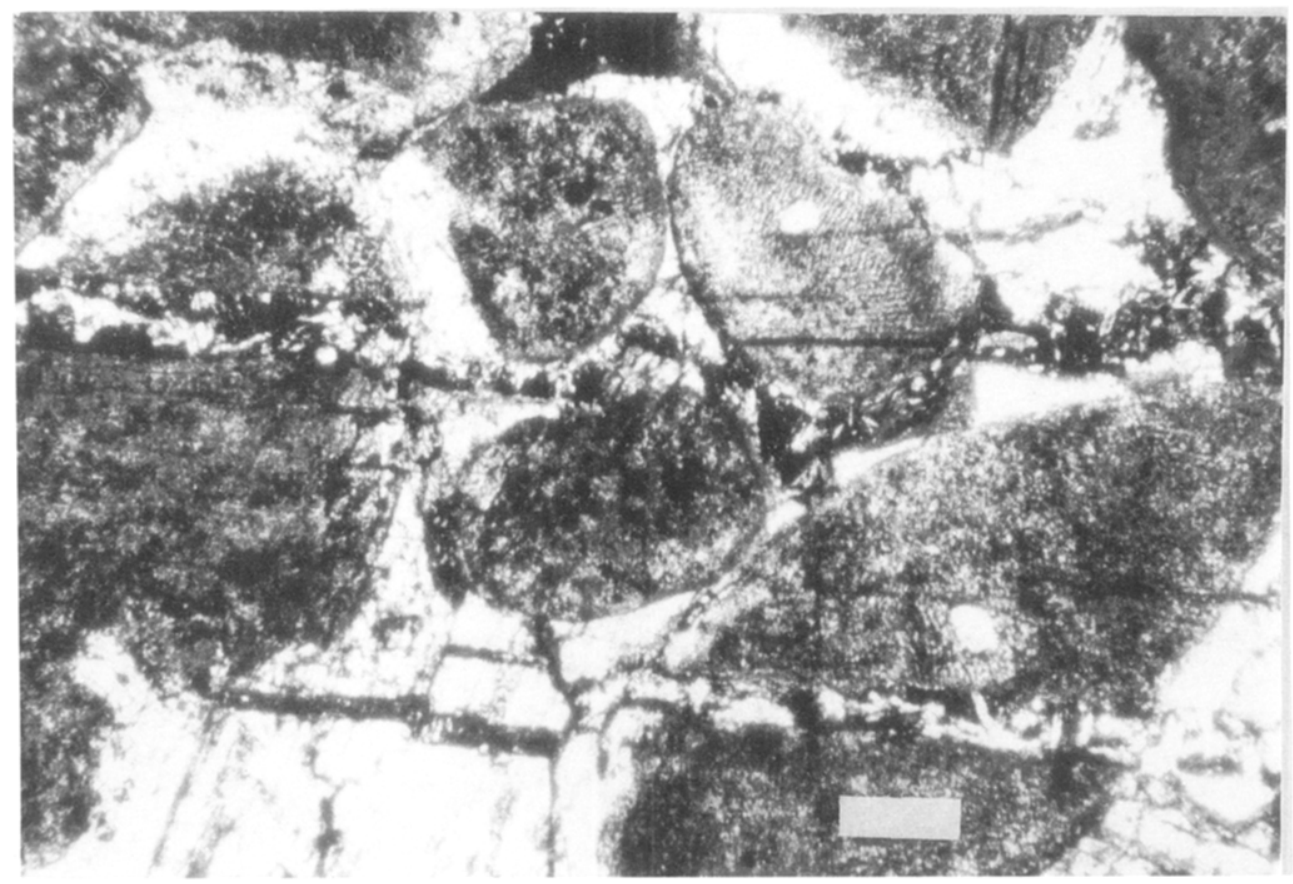

FIGURE 3. Weathered Euville limestone from the Mechelen cathedral. The stone consists of monocrystalline bioclastic calcite grains surrounded by a rim of calcite, forming one crystal with its substrate. Two cracks, parallel with the building stone surface, occur between and in the grains. They follow cleavage surfaces in the monocrystalline calcite grains and are partially filled with gypsum. Viewed with crossed polarizers. Scale bar, $100 \mu \mathrm{m}$.

fine-grained equidimensional crystals and a smaller amount of elongated crystals. The crust also contains quartz grains and opaque particles. Its thickness amounts to $1-3 \mathrm{~mm}$, without mushroom-shaped structures. The stone itself is often impregnated by patches of gypsum, occurring around quartz and glauconite grains but also in the matrix. Patches may be welded together to larger zones. Gypsum also occurs as veins in undulating cracks, running parallel with the outer surface. By EPXMA, bar-shaped and platy gypsum crystals were observed in the crust. Such structures are common in gypsum crusts and were also observed earlier in samples from the Mechelen cathedral (5).

Euville Limestone. Euville stone, used as replacement stone during a restoration campaign nearly a century ago, is a porous, coarse-grained limestone. Observed with the petrographical microscope, each grain consists of a monocrystalline aggregate of a crinoid ossicle and a calcite overgrowth, forming the cement of the stone.

The black crusts, sharply delimited from the underlying stone, are layered. The innermost part consists of nearly isotropic, cryptocrystalline material. Outward, one or two layers with clear, elongated gypsum crystals are observed. The outer border is a continuous thin opaque rim sometimes covered by a small crust of cryptocrystalline gypsum. The thickness and shape of the surfacial gypsum crust are very irregular. Gypsum may build $2-3 \mathrm{~mm}$ thick mushroom-shaped structures, mostly consisting of black, cryptocrystalline material, rich in dust and soot. Clear gypsum is found only near the outer border.

In the stone, minor amounts of gypsum were also observed in pores between the crinoid grains or in cracks running parallel with the stone surface and cutting the grains (Figure 3). These cracks follow crystal cleavage surfaces in the monocrystalline calcite grains.

Massangis Limestone. During repairs at the balustrades at the $95 \mathrm{~m}$ level balcony around 1974, Massangis limestone was applied. After 15 years, some of the stone surfaces were already covered with a black crust. Massangis limestone consists mainly of oölithic and calcareous fossil material, usually rounded and up to $2-3 \mathrm{~mm}$ across. Most of their original structure has been replaced by microsparitic or micritic calcite. Cement is formed by clear sparitic calcite, the diameter of individual crystals ranging between $100 \mu \mathrm{m}$ and $1.5 \mathrm{~mm}$. Some intergranular pores remained open.

A thin surfacial crust was observed on most of the samples studied. The thickness ranges between 30 and $150 \mu \mathrm{m}$ in depressions in the stone surface. The black crusts of many samples consist of isotropic material, often very rich in particles of external origin. The most abundant materials are opaque grains, iron oxides, glauconite, quartz, glassy particles, and calcite grains. Opaque particles are up to $30 \mu \mathrm{m}$ across and may be angular, rounded, or vacuolar. The pores of the vacuolar particles are filled with gypsum. Isotropic spherical glass particles $(<10 \mu \mathrm{m})$ are most probably fly ash. Calcite originates from the stone itself. The distribution of these opaque particles in the crust is very irregular. They may be concentrated in the outer surface or equally dispersed throughout the whole crust. Sometimes, the crust consists of only a single layer of particles in a gypsum matrix.

Calcite, provided by the stone, is found in the crust, sometimes as aggregates of micrite grains, several tens of micrometers in diameter, but mostly as individual crystal grains. In some crusts, the inner part is rather rich in calcite grains. Their concentration gradually diminishes in the outward direction. In some samples, the crust is locally dominated by such calcite grains. However, the limit between a calcite-containing crust and the stone is always sharp. Locally, a thin rim of more or less loose calcite is the only kind of damage observed. Weathering features within the stone are rare. Often, thin brown streaks are observed at $50-150 \mu \mathrm{m}$ under the stone surface or at the 


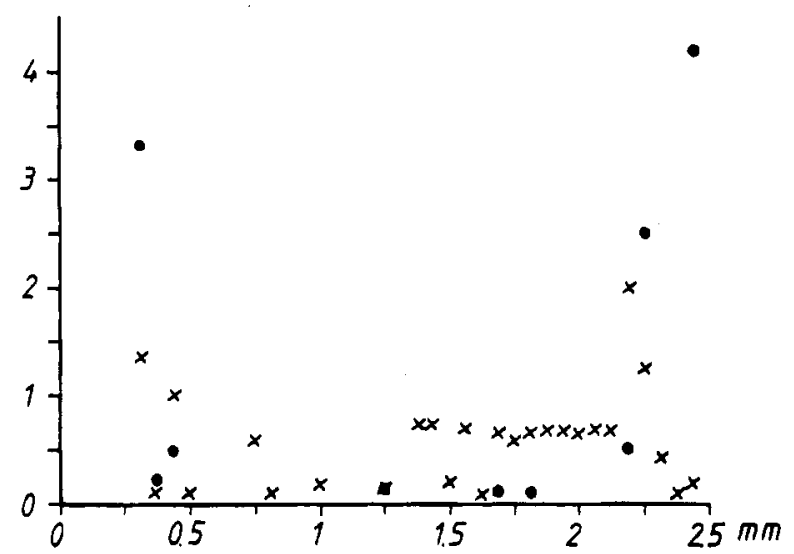

FIGURE 4. EPXMA-profile of a thin section of sample SEV2, showing $\mathrm{S} / \mathrm{Ca}$ and $\mathrm{Fe} / \mathrm{Ca}$ ratios. The gypsum crust is found at the right side (from $1.3 \mathrm{~mm}$ on). Its outer border is marked by increased amounts of Fe. Apparently, grpsum is also locally present in the stone.

contact between the stone and the crust. No gypsum is observed under the crust.

Clearly crystalline gypsum was observed in two samples. In a thin section of a crust from a southern balustrade, the gypsum layer is $300-700 \mu \mathrm{m}$ thick. Gypsum is found as equidimensional or elongated crystals. Upon this crust, rounded and elongated bulges (up to $300 \mu \mathrm{m}$ ) of gypsum occur. They contain relatively large gypsum crystals (maximum, $70 \mu \mathrm{m}$ ). These structures clearly represent early stages of "gypsum mushrooms", like those observed on crusts of longer exposed Balegem and Euville limestones from the Mechelen cathedral. In a sample from the western side, the gypsum crust is thinner $(60 \mu \mathrm{m})$ and consists mainly of a single gypsum crystal layer. Care should be taken when judging the influence of the orientation of the stone. The samples are from a sculpted balustrade. The $95 \mathrm{~m}$ level balcony of the Mechelen cathedral is a very windy spot, with unpredictable wind turbulence due to the large buttresses of the tower and the irregular basements of the never-completed spire.

Elements and Inorganic Compounds in Crusts and Stones. Element Concentration Profiles in Crusts and Stones. In EPXMA profiles of thin sections, black crusts are characterized by $S / C a$ ratios between 0.7 and 1 and by the occurrence of one or more elements like $\mathrm{Fe}, \mathrm{Mg}, \mathrm{Na}$, $\mathrm{Si}, \mathrm{K}$, and sometimes $\mathrm{Pb}$ and $\mathrm{Cu}$. Quartz grains in the stone are marked by high $\mathrm{Si} / \mathrm{Ca}$ values (up to 200). In Balegem stone, a few glauconite grains were identified by elevated ratios of $\mathrm{Si} / \mathrm{Ca}, \mathrm{Fe} / \mathrm{Ca}, \mathrm{K} / \mathrm{Ca}$, and occasionally $\mathrm{Mg} / \mathrm{Ca}$. Some samples (MECH1, MECH2, and SEV2) contain zones with $\mathrm{S} / \mathrm{Ca}$ ratios between 1 and 2 in the stone (Figure 4 ). In the EPXMA profiles of other analyzed samples (SEVI, SEV5a, and SEV5b), S was encountered only at a few distinct spots.

Elemental Concentrations in Crusts and Stones. Two stone samples and one crust of Balegem stone, a Gobertange limestone sample (Mechelen cathedral), and two samples from Sevilla with their crusts were analyzed by NAA and XRF.

The lowest values for $\mathrm{Ca}$ were found in the Balegem sandy limestone (21\%), the highest $(44 \%)$ in the rather pure limestone from Sevilla. The Ca concentration of the slightly sandy Gobertange stone is in between. Compared with the corresponding stone, the crusts contain between 20 and $50 \%$ less $\mathrm{Ca}$. The Balegem limestones contain up to $1 \% \mathrm{Fe}$; this may be explained by the high amount of glauconite and the presence of ferroan calcite. Varying amounts of $\mathrm{Fe}(0.1-0.5 \%)$ are found in the Sevilla stone, which contains iron oxides, causing its ochrous stain (2). The crusts are all enriched in Fe. Potassium is present in clay minerals and also in glauconite and feldspar (Balegem stone). This element is enriched in the crusts from Sevilla $(0.4-1.0 \%)$ relative to the stone (up to $0.2 \%$ ), but for the Balegem stone, the crust contains less $\mathrm{K}$ than the rock $(0.4$ vs. $0.9 \%$ ). The most obvious source of $\mathrm{Na}$ in Balegem stone $(0.15 \%)$ is also feldspar. Like $\mathrm{K}, \mathrm{Na}$ enrichment in the crust is important in samples from Sevilla $(0.3-0.04 \%$ vs. $0.07-$ $0.09 \%$ in the stone) but not in those from Mechelen $(0.15 \%)$.

Concentrations of $100-1000 \mathrm{ppm}$ (concentrations in the stone) of $\mathrm{Ti}, \mathrm{Mn}, \mathrm{Sr}$, and $\mathrm{Ba}$ are found. Titanium is clearly enriched in all crusts relative to the stone, with average concentrations of $\sim 600 \mathrm{vs.} 150 \mathrm{ppm}$ for Mechelen and 700 vs. $300 \mathrm{ppm}$ for Sevilla; this may be due to soil dust. The Mn levels were $100-200 \mathrm{ppm}$ in all samples. In limestone, Sr occurs as a minor substitution in aragonite in fossils. The high amount of $\mathrm{Sr}$ in Gobertange stone (200 ppm) is due to the larger amount of biogenic micrite in this material. Crusts from Mechelen show an enrichment in Sr (1200 $\mathrm{ppm}$ ), but those from Sevilla do not $(300-700 \mathrm{ppm}$ in stones and crusts). The most important element of unknown origin, particularly in Balegem stone, is $\mathrm{Ba}$. Its concentration of $180 \mathrm{ppm}$ is close to the maximum found in marine limestone (9). No Ba mineral is known in Balegem stone, but considering the marine origin of the sediment, barite $\left(\mathrm{BaSO}_{4}\right)$ is not unlikely. In the crust on Balegem stone, $\mathrm{Ba}$ is not significantly enriched compared to the stone. In the Sevilla samples, the crust/stone ratio for $\mathrm{Ba}$ is about 10 , and absolute amounts in the crusts are close to the concentrations in Balegem stone and their crusts. A possible external source for the higher enrichments in the Sevilla samples may be diesel exhaust.

In the range between 10 and $100 \mathrm{ppm}, \mathrm{Cr}, \mathrm{Cu}, \mathrm{Zn}, \mathrm{Rb}$, and $\mathrm{Zr}$ are found. $\mathrm{Cr}$ is most abundant in the Balegem stone (26 ppm) and is slightly enriched in all crusts. All stones contain $\sim 12 \mathrm{ppm} \mathrm{Cu}$, but the crusts are all enriched to $70 \mathrm{ppm} \mathrm{Cu}$. The $\mathrm{Zn}$ concentrations were around $15 \mathrm{ppm}$ in the stones but $150 \mathrm{ppm}$ in the crusts of both cathedrals. On the average, $\mathrm{Rb}$ is only slightly enriched in the crusts $(20 \mathrm{vs} .8 \mathrm{ppm})$. Balegem stone contains a small amount of zircon $\left(\mathrm{ZrSiO}_{4}\right)$ grains in its detrital fraction (10), corresponding to $100 \mathrm{ppm} \mathrm{Zr}$. The mineral is also present in Gobertange stone and in the Sevilla samples, but in lower amounts (below $20 \mathrm{ppm}$ ). Of all minerals, zircon is known as the most stable against weathering and is therefore ubiquitous. It thus may also occur in dust of external origin.

In all stones, $\mathrm{Ni}, \mathrm{As}, \mathrm{Br}$, and $\mathrm{Pb}$ were present around 3 ppm, but in the crusts, their levels were on the average around $10,40,15$, and $150 \mathrm{ppm}$, respectively, indicative of an external (pollution) source. Other elements detected by NAA or XRF at the ppm or sub-ppm level were V, Co, $\mathrm{Ga}, \mathrm{Se}, \mathrm{Sb}, \mathrm{Cs}$, some rare earths, $\mathrm{Hf}, \mathrm{W}, \mathrm{Au}, \mathrm{Th}$, and $\mathrm{U}$. Noteworthy were only the higher concentration $(2.5 \mathrm{ppm})$ of $U$ in the Balegem stone and the strong enrichment factors in the crust for $\mathrm{Sb}$ (on the average $8 \mathrm{ppm}$ in the crusts vs. $0.3 \mathrm{ppm}$ in the stones) and for $\mathrm{Au}$ in Sevilla samples $(0.3$ vs. $0.007 \mathrm{ppm}$ ).

Leachable Ions in the Crust. Analytical results of leached ions are listed in Tables 1 (anions) and 2 (cations). Concentrations of $\mathrm{Ca}^{2+}$ and $\mathrm{SO}_{4}{ }^{2-}$ are stoichiometrically 
TABLE 1

Results of IC Analyses (in wt \%) of Crust Samples Leached in $\mathrm{H}_{2} \mathrm{O}$ and $0.1 \mathrm{~N} \mathrm{HCl}$ (Means of Three and Two Determinations, Respectively)

\begin{tabular}{|c|c|c|c|c|c|c|c|c|}
\hline \multirow[b]{2}{*}{ sample } & \multicolumn{2}{|c|}{$\mathrm{Cl}^{-}$} & \multicolumn{2}{|c|}{$\mathrm{NO}_{3}{ }^{-}$} & \multicolumn{2}{|c|}{$\mathrm{SO}_{4}{ }^{2-}$} & \multicolumn{2}{|c|}{$\mathrm{PO}_{4}{ }^{3-}$} \\
\hline & $\mathrm{H}_{2} \mathrm{O}$ & $\mathrm{HCl}$ & $\mathrm{H}_{2} \mathrm{O}$ & $\mathrm{HCl}$ & $\mathrm{H}_{2} \mathrm{O}$ & $\mathrm{HCl}$ & $\mathrm{H}_{2} \mathrm{O}$ & $\mathrm{HCl}$ \\
\hline $\begin{array}{l}\text { SEV2 } \\
\text { SEV3 } \\
\text { SEV4 } \\
\text { SEV5a } \\
\text { SEV 5b } \\
\text { UECH1 } \\
\text { UECH } 2\end{array}$ & $\begin{array}{c}21 \\
0.86 \\
16 \\
20 \\
25 \\
16 \\
6.5 \\
15 \\
16 \\
24\end{array}$ & $\begin{array}{l}a \\
a \\
a \\
a \\
a \\
a \\
a \\
a \\
a \\
a\end{array}$ & $\begin{array}{l}0.41 \\
0.91 \\
1.7 \\
8.1 \\
2.0 \\
0.29 \\
0.31 \\
0.98 \\
0.40\end{array}$ & $\begin{array}{l}6.0 \\
5.2 \\
4.8 \\
3.0 \\
7.4 \\
3.8 \\
3.8 \\
4.6 \\
8.5\end{array}$ & $\begin{array}{c}73 \\
82 \\
9.7 \\
3.1 \\
110 \\
6.2 \\
110 \\
130 \\
160 \\
150\end{array}$ & $\begin{array}{c}66 \\
75 \\
15 \\
7.2 \\
110 \\
19 \\
110 \\
130 \\
150 \\
160\end{array}$ & $\begin{array}{l}b \\
b \\
b \\
b \\
0.73 \\
0.72 \\
b \\
b \\
b \\
b\end{array}$ & $\begin{array}{l}b \\
b \\
b \\
b \\
16 \\
30 \\
b \\
b \\
b \\
b\end{array}$ \\
\hline
\end{tabular}

${ }^{a}$ Not measured. ${ }^{b}$ Not detected.

\section{TABLE 2}

Results of AAS and AES Analyses (in wt \%) of Crust Samples Leached in $\mathrm{H}_{2} \mathrm{O}$ and $\mathrm{O} .1 \mathrm{~N} \mathrm{HCI}$ (Means of Three and Five Determinations, Respectively)

\begin{tabular}{|c|c|c|c|c|c|c|c|c|}
\hline \multirow[b]{2}{*}{ sample } & \multicolumn{2}{|c|}{$\mathrm{Ca}^{2+}$} & \multicolumn{2}{|c|}{$\mathrm{mg}^{-}$} & \multicolumn{2}{|c|}{$\mathrm{Na}$} & \\
\hline & $\mathrm{H}_{2} \mathrm{O}$ & $\mathrm{HCl}$ & ${ }_{2} 0$ & $\overline{C I}$ & ${ }_{20}$ & $\mathrm{HCl}$ & $\mathrm{I}_{2} \mathrm{O}$ & ICI \\
\hline $\begin{array}{l} \\
\text { a } \\
b \\
+11 \\
-12\end{array}$ & $\begin{array}{c}38 \\
39 \\
7.4 \\
5.6 \\
58 \\
7.2 \\
55 \\
62 \\
71\end{array}$ & $\begin{array}{r}110 \\
74 \\
110 \\
72 \\
77 \\
92 \\
90\end{array}$ & & & $\begin{array}{l}1 \\
1 \\
7 \\
7\end{array}$ & 0.5 & $\begin{array}{l}0.09 \\
0.05 \\
0.19 \\
0.66 \\
0.11 \\
0.70 \\
0.51 \\
0.77 \\
0.27\end{array}$ & $\begin{array}{l}0.53 \\
1.0 \\
0.68 \\
1.0 \\
0.41\end{array}$ \\
\hline
\end{tabular}

comparable to each other. The highest amounts of these ions were measured in samples from Mechelen, probably because the crusts from the Sevilla samples were thinner. The ratio leachate $(\mathrm{HCl}) /$ leachate $\left(\mathrm{H}_{2} \mathrm{O}\right)$ for $\mathrm{SO}_{4}{ }^{2-}$ is nearly 1. Samples with very low amounts of $\mathrm{SO}_{4}{ }^{2-}$ (SEV3, SEV4, and SEV5b) in the aqueous solutions show higher ratios (1.6-3.1). The ratio leachate $(\mathrm{HCl}) /$ leachate $\left(\mathrm{H}_{2} \mathrm{O}\right)$ for $\mathrm{Ca}^{2+}$ amounts to about 1.3 in the samples from Mechelen and in the sample from Sevilla with the highest amount of $\mathrm{SO}_{4}{ }^{2-}$ (SEV5a). The other samples from Sevilla show an increasing ratio for $\mathrm{Ca}$ (up to 19) with decreasing concentrations of $\mathrm{SO}_{4}{ }^{2-}$. The latter crust samples were thin and contaminated with calcite particles from the stone, which are dissolved in the acid leachates. Clearly, the leaching in water dissolved all the sulfate present in the crusts. Only when the sulfate-concentrations were low did dissolution of enclosing calcite in $\mathrm{HCl}$ set free extra amounts. Because $\mathrm{Mg}$ may be present in calcite lattices, higher leachate $(\mathrm{HCl})$ / leachate $\left(\mathrm{H}_{2} \mathrm{O}\right)$ ratios for this ion are found in the Sevilla samples.

Chloride concentrations vary between 15 and $25 \%$, except for two samples. No relationships with other ions are observed. Stoichiometrically, $\mathrm{Cl}$ and $\mathrm{Na}$ differ largely from each other $(50 \times$ more chloride was measured). of course, $\mathrm{Cl}$ was not determined in the solutions leached with $\mathrm{HCl}$. Nitrate concentrations are higher in the samples from Sevilla than in those from Mechelen. Solutions leached in $\mathrm{HCl}$ gave $\mathrm{NO}_{3}{ }^{-}$concentrations up to $15 \times$ higher
TABLE 3

Composition of 10 Specific Particle Types in the Insoluble Fraction from HCl-Leached Crusts for Sevilla Cathedral Sample SEV4a

$\begin{array}{cccccccccccc}\begin{array}{c}\text { particle } \\ \text { type no. }\end{array} & \mathbf{M g} & \mathbf{A l} & \mathbf{S i} & \mathbf{S} & \mathbf{C l} & \mathbf{K} & \mathbf{C a} & \mathrm{Ti} & \mathbf{F e} & \mathbf{C u} & \mathbf{Z n} \\ 1 & 0 & 0.13 & 99 & 0.05 & 0.03 & 0.21 & 0.03 & 0 & 0.9 & 0 & 0 \\ 2 & 0.15 & 23 & 63 & 0.95 & 1.4 & 3.1 & 0.05 & 0.2 & 8.1 & 0 & 0 \\ 3 & 1.3 & 5 & 52 & 0 & 10 & 0 & 6.5 & 4.6 & 6.5 & 0 & 0 \\ 4 & 0 & 15 & 48 & 0 & 0.19 & 3 & 0.15 & 0.8 & 31 & 0 & 0 \\ 5 & 0 & 4.5 & 10 & 0 & 0.72 & 0 & 0 & 0 & 84 & 0 & 0 \\ 6 & 11 & 0 & 1.3 & 0 & 0 & 0 & 0 & 0 & 2.3 & 0 & 0 \\ 7 & 0 & 0 & 0 & 0 & 0 & 2.9 & 0 & 97 & 0 & 0 & 0 \\ 8 & 0 & 0 & 0 & 0 & 0 & 21 & 0 & 0 & 0 & 0 & 79 \\ 9 & 0 & 0 & 0 & 0 & 0 & 0 & 93 & 0 & 0 & 0 & 0 \\ 10 & 0 & 0 & 1.4 & 64 & 0 & 0 & 0 & 0 & 28 & 6.5 & 0\end{array}$

a The numbers are not elemental concentrations but relative intensities of the characteristic $X$-rays emitted by the elements.

than those leached in water. Oxalate salts were not detected in acid leachates. Two samples from Sevilla contain some phosphate, probably of biological origin, as bird droppings are common on the nave roofs. Concentrations of cations other than $\mathrm{Ca}$ are lower than those of anions, and no relationship can be found between them.

Individual Particle Types in the Insoluble Fraction of the Crusts. The results of the automated EPXMA on the particulate matter remaining after $\mathrm{HCl}$ dissolution were processed with hierarchical and nonhierarchical cluster analysis, as described by Xhoffer et al. (7). In this way, all individual particles were classified into specific groups with a similar chemical composition. This allowed about 10 major populations to be distinguished. As an example, Table 3 shows the average composition of the 10 different particle groups that were identified in SEV4. For all samples, the most important cluster $(67-86 \%$ of all detected particles) is dominated by $\mathrm{Si}$ and $\mathrm{Si}-\mathrm{Al}$. In all the measured samples, a cluster with $\mathrm{Si}$ as major element $(90-100 \%$ of the detected X-rays), probably quartz dust, was present (e.g., particle type 1 in Table 3 ). Several combinations of $\mathrm{Si}(50-70 \%$ of the detected X-rays) and $\mathrm{Al}(10-30 \%)$, mostly with $\mathrm{Fe}(0-$ $30 \%)$ and sometimes $K(1-10 \%)$, were found in all the samples (e.g., types 2,3 , and 4 in Table 3 ). The $\mathrm{Si}-\mathrm{Al}$ clusters most probably mark clay minerals, glauconite (the $\mathrm{K}$ bearing group in Mechelen), or fly ash. In the second group of clusters $(6-12 \%$ in samples from Sevilla, $14-23 \%$ in those from Mechelen), $\mathrm{Fe}$ is the main element. Nearly all the samples contain a cluster with $\mathrm{Fe}(80-90 \%$ of the detected $\mathrm{X}$-rays), $\mathrm{Si}(1-10 \%)$, and $\mathrm{Al}$ (maximum, $5 \%$ ), e.g., particle type 5 in Table 3. In Mechelen, a particle type with only Fe as an X-ray-detectable element was observed. Iron oxides were observed in thin sections of crusts. This might be related to the scaffolding around the building. The relative abundance of the third group ranges between 1 and $10 \%$; it is characterized by the absence of a dominating X-raydetectable element (e.g., type 6 in Table 3). Probably, this group includes mainly organic particles. The fourth group is a combination of three cluster subgroups dominated by metals: Ti (e.g., type 7 in Table 3), Cu, or $\mathrm{Zn} \mathrm{(e.g.,} \mathrm{type} 8$ in Table 3). The group is more important in crusts from Sevilla $(0.7-11 \%$ of all particles) than in those from Mechelen (0.7-1.3\%). In most of the samples, a Ti-rich (60-90\% of the detected X-rays) cluster with minor amounts of $\mathrm{Si}$ and $\mathrm{Fe}$ (up to $20 \%$ ) was found. In some Mechelen samples, the abundance of $\mathrm{Ti}-\mathrm{Fe}-\mathrm{Si}$ was nearly equal. Clusters containing up to $100 \% \mathrm{Cu}$ or $\mathrm{Zn}$ were more 


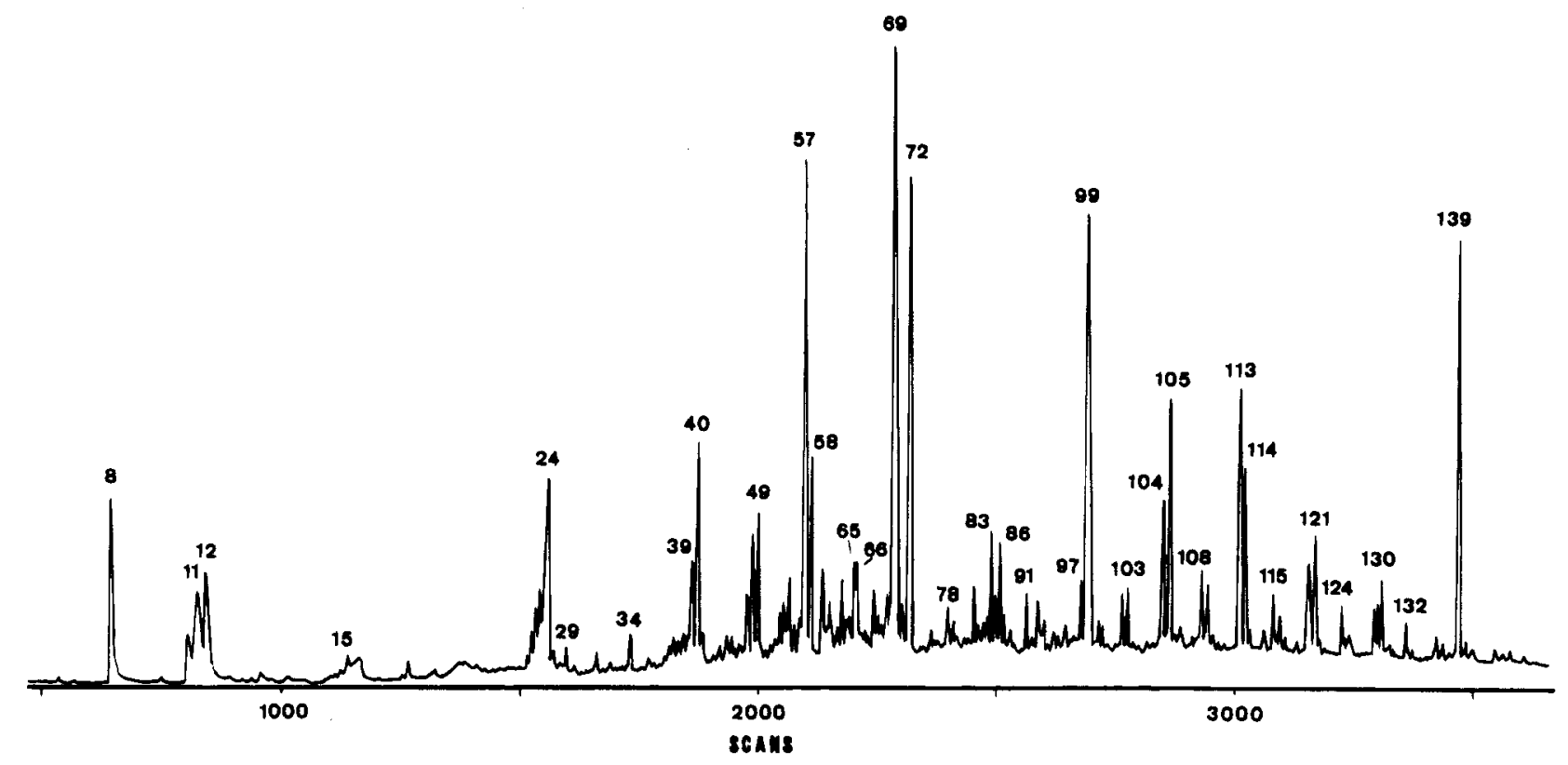

FIGURE 5. Typical GC/MS results. The numbers on the peaks refer to the compounds listed in Table 4.

abundant in Sevilla than in Mechelen. A fifth group (e.g., type 9 in Table 3) with variable abundance contains only $\mathrm{Ca}$ as an X-ray-detectable element. These are $\mathrm{CaCO}_{3}$ particles released from the disintegrating limestone matrix or recrystallized from it. In the samples from Mechelen (up to $2 \%$ ) and some from Sevilla (up to $1 \%$ ), a S-rich ( $70 \%$ ) group of particles, with Fe (up to $28 \%$ ) and $S(\sim 5 \%)$ as secondary elements, is encountered (e.g., type 10 in Table 3). Possible S-containing particles are organic compounds resulting from combustion and deposition of fly ash (presence of Fe and $\mathrm{Si}$ ). Coal may contain $\mathrm{S}$ compounds of organic and inorganic origin, although most of them are expected to be oxidized during combustion. The remaining groups were not found in all the samples. Chlorine-rich particles (abundance up to $2.1 \%$ in Sevilla, $0.7 \%$ in Mechelen) contain $\mathrm{Cl}(\sim 80 \%$ of the detected characteristic $\mathrm{X}$-rays) and $\mathrm{K}(\sim 13 \%)$. They often contain small amounts of $\mathrm{Zn}$ or $\mathrm{Cu}$. Another minor group (maximum, $1.3 \%$ in Mechelen, $0.7 \%$ in Sevilla) is rich in $\mathrm{Al}$ ( $64 \%$ of the detected $\mathrm{X}$-rays) and $\mathrm{Fe}$ (15\%). Minor amounts of $\mathrm{Si}, \mathrm{P}$, and $\mathrm{S}$ (maximum, 5\%) were detected. This group could represent fly ash particles rich in mullite $\left(3 \mathrm{Al}_{2} \mathrm{O}_{3} . \mathrm{SiO}_{2}\right)$, a mineral formed from clay particles during combustion of coal, and hematite $\left(\mathrm{Fe}_{2} \mathrm{O}_{3}\right)$ resulting from oxidation of pyrite $\left(\mathrm{FeS}_{2}\right)$, present in coal. Finally, the smallest cluster group (maximum, $0.7 \%$ abundance) is characterized by $\mathrm{Cr}(65 \%)$ and $\mathrm{Si}(30 \%)$. The reason for this combination is not clear.

Organic Compounds. Saiz-Jimenez (11) has demonstrated that the black crusts coating the surfaces of buildings in urban environments contain various organic compounds derived from aerosols. The elemental $\mathrm{C}, \mathrm{H}, \mathrm{N}$, and $\mathrm{S}$ contents of some crust samples, collected in the south and west fronts of the Sevilla cathedral and the south walls of the Mechelen cathedral were determined. The results were similar for all samples: $3.5-4.8 \% \mathrm{C}, \sim 1.4 \% \mathrm{H}, 0.14-0.19 \%$ $\mathrm{N}, 10-12 \% \mathrm{~S}$. The ash content was $76-78 \%$ in all cases. The organic carbon immobilized in the superficial crusts of monuments can be extracted with toluene followed by methanol (12). The extracted compounds, identified by GC/MS, are listed in Table 4, and the numbers refer to the peaks Figure 5. These compounds were ordered in classes for a more rational presentation.
$n$-Alkanes. Straight-chain alkanes were identified in both Sevilla and Mechelen extracts. The range was $n-\mathrm{C}_{5}$ to $n-\mathrm{C}_{40}$, which is in the limit of the analytical procedure used. However, $n$-alkanes higher than $n$ - $\mathrm{C}_{40}$ could, in all probability, be identified using recently developed high-temperature GC (13). The Sevilla extract chromatograms exhibit a typical broad envelope of unresolved compounds, commonly found in petroleum derivatives, ranging approximately from $n-\mathrm{C}_{15}$ to $n-\mathrm{C}_{35}$, which was not observed in the Mechelen sample. Resolved compounds surmounting this envelope were identified.

For investigating sources of homologous series of compounds, the "carbon preference index" (CPI), which is the sum of the odd-carbon-number homologues over a specified range divided by the sum of the even-carbonnumber homologues over the same range, was utilized. Also, a more sensitive method requiring splitting of the carbon range into low $\left(\mathrm{C}_{15}-\mathrm{C}_{24}\right)$ and high ends $\left(\mathrm{C}_{25}-\mathrm{C}_{34}\right)$ was employed. In such cases, the total CPI for the Sevilla extract was 1.0, and the low and high ends were 0.8 and 1.1, respectively. For the Mechelen extracts, they were 1.7, 1.1, and 2.1, respectively. In both cases, the lower ends were representative of a petrogenic origin, as the typical CPI of petroleum is 1.0 , and petroleum derivatives are a major and usually predominant component of the lipids extractable from aerosols in urban environments (14). The high end in the case of Sevilla was also characteristic of petroleum, but that of Mechelen demonstrated a plant signature, confirmed by the dominance of $n-C_{29}$, which indicated a probable mixed origin from trees and grassland. Therefore, a bimodal $n$-alkane distribution was observed for the Mechelen sample. The data obtained for Sevilla are not surprising, because diesel engine exhausts from public buses and gasoline automobiles impact directly on the cathedral walls, masking any possible biological contribution.

Among the isoprenoid species, pristane and phytane were identified. They are diagenetic products of phytol and are not primary constituents of terrestrial biota (15). These $\mathrm{C}_{19}$ and $\mathrm{C}_{20}$ isoprenoids are commonly distributed in petroleum, since they are not separated in the refining processes, and have been encountered in environmental 


\section{TABLE 4}

\section{Organic Compounds Identified in the Black Crusts of Sevilla and Mechelen Cathedrals ${ }^{a}$}

\begin{tabular}{|c|c|c|c|c|c|c|c|}
\hline peak & compound & Sevilla & Mechelen & peak & compound & Sevilla & Mechelen \\
\hline 1 & acetone + iodomethane & + & - & 75 & methylalkylbenzene & + & - \\
\hline 2 & $n$-pent-1-ene & + & - & 76 & methylpyrene & + & - \\
\hline 3 & methylfuran $+n$-pentane & + & - & 77 & retene & + & - \\
\hline 4 & benzene & + & + & 78 & $n$-docosane + & ++ & + \\
\hline 5 & toluene & + & + & & $n$-C 20 -alkan-2-one & + & - \\
\hline 6 & $\mathrm{C}_{2}$-alkylbenzene & + & - & 79 & methyl $n$-nonadecanoate & + & + \\
\hline 7 & styrene & + & + & 80 & methyl 9,10-epoxyoctadecanoate & - & + \\
\hline 8 & benzaldehyde & ++ & ++ & 81 & $\mathrm{C}_{23}$-tricyclic terpane & + & - \\
\hline 9 & chloromethylbenzene & + & + & 82 & 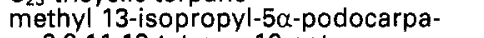 & + & + \\
\hline 10 & benzeneacetaldehyde & + & + & & $6,8,11,13$-tetraen-16-oate & & \\
\hline 11 & benzenemethanol & +++ & + & 83 & methyl dehydroabietate & + & ++ \\
\hline 12 & acetophenone & +++ & + & 84 & n-tricosane & ++ & + \\
\hline 13 & $\mathrm{C}_{4}$-alkylbenzene & + & + & 85 & benzofluorenone & + & - \\
\hline 14 & benzothiazole & + & + & 86 & methyl n-eicosanoate & +++ & ++ \\
\hline 15 & 2,3-dihydrobenzo[b]thiophene & - & + & 87 & benzol $b]$ naphtho(2,1-d) thiophene & - & + \\
\hline 16 & methyl benzoate & + & + & 88 & benzolc]phenanthrene & + & - \\
\hline 17 & methyl benzenepropanoate & + & - & 89 & benzolghilfluoranthene & + & + \\
\hline 18 & benzoyl chloride & + & - & 90 & benzanthracenone & + & - \\
\hline 19 & methyl anisate & + & - & 91 & dioctyl adipate & + & + \\
\hline 20 & biphenylene & + & - & 92 & $n$-tetracosane & ++ & $\div$ \\
\hline 21 & methyl 4-tert-butylbenzoate & + & - & 93 & benzla]anthracene & + & + \\
\hline 22 & dimethyl phthalate & + & - & 94 & methyl $n$-heneicosanoate & + & + \\
\hline 23 & methylfluorene & + & - & 95 & chrysene & + & - \\
\hline 24 & 1,2-diphenylethane & ++ & ++ & 96 & $n$-C 2 -alkan-2-one & - & - \\
\hline 25 & di-tert-butylphenol & + & - & 97 & $n$-pentacosane & ++ & - \\
\hline 26 & 1,1-diphenylethane & + & + & 98 & bis(2-ethylhexyl) phthalate & +++ & $++t$ \\
\hline 27 & n-pentadecane & + & - & 99 & methyl n-docosanoate & +++ & +++ \\
\hline 28 & $\mathrm{C}_{2}$-alkylbiphenyl & - & - & 100 & benzlajanthracene-7,12-dione & - & + \\
\hline 29 & methyl $n$-dodecanoate & + & + & 101 & 2,2 -binaphthalene & + & - \\
\hline 30 & dimethyl n-nonanedioate & + & + & 102 & n-hexacosane & ++ & + \\
\hline 31 & diethyl phthalate & + & + & 103 & methyl n-tricosanoate & ++ & + \\
\hline 32 & $n$-C 14 -alkan-2-one & + & - & 104 & n-heptacosane & ++ & ++ \\
\hline 33 & $n$-hexadecane & + & + & 105 & methyl n-tetracosanoate t benzo- & $++\div$ & ++ \\
\hline 34 & $\begin{array}{l}\text { methyl } n \text {-tridecanoate }+ \text { benzyl } \\
\text { ethyl ether }\end{array}$ & + & + & 106 & $\begin{array}{l}\text { fluoranthene } \\
\text { 24-ethyl-5a(t)-cholestane }\end{array}$ & - & + \\
\hline 35 & methylheptylbenzene & + & - & 107 & benzopyrene & + & + \\
\hline 36 & stilbene & + & - & 108 & $n$-octacosane & ++ & + \\
\hline 37 & $9 H$-fluoren-9-one & + & - & 109 & methyl n-pentacosanoate & ++ & + \\
\hline 38 & n-heptadecane + & + & + & 110 & $18 \alpha(H)-22,29,30$-trisnorhopane & - & + \\
\hline & methylfluorenone & - & + & 111 & $17 \alpha(H)-22,29,30$-trisnorhopane & + & + \\
\hline 39 & methyl $n$-tetradecanoate & + & + & 112 & 8,14-secohopane $\left(C_{30}\right\}$ & + & - \\
\hline 40 & benzyl benzoate & ++ & ++ & 113 & $n$-nonacosane & +++ & ++ \\
\hline 41 & phenanthrene & + & + & 114 & methyl n-hexacosanoate & +++ & ++ \\
\hline 42 & 7-methylheptadecane & + & - & 115 & n-triacontane & ++ & + \\
\hline 43 & 9,10 -dihydrophenanthrene + & + & + & 116 & $17 \alpha(H), 21 \beta(H)-30$-norhopane & + & + \\
\hline & $9(10 H)$ anthracenone & & & 117 & methyl $n$-heptacosanoate & + & + \\
\hline 44 & methyl isopentadecanoate & + & - & 118 & $17 \beta(H), 21 \alpha(H)-30$-normoretane & - & + \\
\hline 45 & pristane + & + & - & 119 & $17 \alpha(H), 21 \beta(H)$-hopane & + & + \\
\hline & methyl isopentadecanoate & + & + & 120 & $n$-hentriacontane & +++ & + \\
\hline 46 & $n$-octadec-1-ene & + & + & 121 & methyl n-octacosanoate & +++ & ++ \\
\hline 47 & $n$-octadecane & + & + & 122 & $17 \beta(H), 21 \alpha(H)$-moretane & + & + \\
\hline 48 & methyl n-pentadecanoate & ++ & ++ & 123 & $17 \alpha(H), 21 \beta(H)$-homohopane (22S) & + & + \\
\hline 49 & diisobutyl phthalate & + & -+ & 124 & $n$-dotriacontane & ++ & + \\
\hline 50 & phytane & + & - & 125 & $17 \alpha(H), 21 \beta(H)$-homohopane $(22 R)$ & + & + \\
\hline 51 & methylphenanthrene & + & + & 126 & methyl $n$-nonacosanoate & + & + \\
\hline 52 & methyl isohexadecanoate & + & + & $1 \overline{2}$ & $17 \alpha(H), 21 \beta(H)$-bishomohopane $(22 S)$ & + & + \\
\hline 53 & di-sec-butyl phthalate & + & + & 12 & $n$-tritriacontane + & ++ & + \\
\hline 54 & methylphenanthrene & + & - & & $17 \alpha(H), 21 \beta(H)$ bishomohopane $(22 R)$ & + & + \\
\hline 55 & methyl isohexadecanoate & + & + & 129 & $n-C_{31}$-alkan-2-one & - & + \\
\hline 56 & n-nonadecane & + & + & 130 & methyl n-tritriacontanoate & ++ & + \\
\hline 57 & methyl $n$-hexadecanoate & +++ & +++ & 13 & $17 \alpha(H), 21 \beta(H)$-trishomohopane (22S) & + & + \\
\hline 58 & di-n-butyl phthalate & + & ++ & 13 & $n$-tetratriacontane & ++ & + \\
\hline 59 & 1,3-diphenyl-2-propen-1-one & ++ & + & 13 & $17 \alpha(H), 21 \beta(H)$-trishomohopane $(22 R)$ & + & + \\
\hline 60 & $\mathrm{C}_{2}$-alkylphenanthrene & - & + & 13 & methyl $n$-hentriacontanoate & + & + \\
\hline 61 & methyl isoheptadecanoate & + & - & 135 & $17 \alpha(H), 21 \beta(H)$-tetra- & + & + \\
\hline 62 & methylalkylbenzene + & + & - & & kishomohopane (22S) & & \\
\hline & methyl isoheptadecanoate & + & + & 136 & $n$-pentatriacontane & + & + \\
\hline 63 & $\mathrm{C}_{2}$-alkylphenanthrene & $\div$ & - & 137 & $17 \alpha(H), 21 \beta(H)$-tetra- & + & + \\
\hline 64 & n-eicosane & ++ & + & & kishomohopane (22R) & & \\
\hline 65 & fluoranthene & + & + & 138 & methyl $n$-dotriacontanoate & + & + \\
\hline $\begin{array}{l}66 \\
67\end{array}$ & $\begin{array}{l}\text { methyl n-heptadecanoate } \\
\mathrm{C}_{2} \text {-alkylphenanthrene }\end{array}$ & $\stackrel{i+}{i}+$ & + & 139 & $\begin{array}{l}\text { unknown, possibly a methyl- } \\
\text { substituted dibenzopyrene }\end{array}$ & ++ & ++ \\
\hline 68 & pyrene & ++ & + & 140 & $17 \alpha(H), 21 \beta(H)$-pentakis- & - & 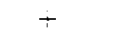 \\
\hline 69 & methyl n-octadec-1-enoate & ++ & +++ & & homohopane & & \\
\hline 70 & methyl isooctadecanoate & + & - & 141 & $n$-hexatriacontane & + & + \\
\hline 71 & $n$-heneicosane + & ++ & + & 142 & n-heptatriacontane & + & + \\
\hline & methyl isooctadecanoate & + & - & $14 \overline{3}$ & n-octatriacontane & + & + \\
\hline & methyl n-octadecanoate & +++ & +++ & 144 & n-nonatriacontane & + & + \\
\hline 73 & alkylbenzene & - & - & 145 & $n$-tetracontane & + & - \\
\hline 74 & methylpyrene & - & + & & & & \\
\hline
\end{tabular}

antensities ranges from "-w" (which denotes absence) to " $+"(<25 \%), "++"(25-50 \%)$, and " +++ " $(>50 \%)$, referenced to the highest peaks namely, methyl n-octadec-1-enoate in Mechelen and methyl n-docosanoate in Sevilla (100\%).

aerosols, exhausts from auto and diesel engines, diesel fuel, and lubricating oil.

The unresolved complex mixture of branched and cyclic structures in the Sevilla extract adds further evidence to a petroleum origin for the mixture of compounds. Such a big hump was generally observed in aerosols from highly polluted areas, and it is most probably associated with exhausts. In fact, the hump is the reflection of the 
deposition of partially uncombusted fuels generated by the high traffic activity.

Ketones. In the mixture of extracted compounds, only the $\mathrm{C}_{14}, \mathrm{C}_{20}, \mathrm{C}_{22}$, and $\mathrm{C}_{31}$ ketones were identified. A series of ketones ranging from $\mathrm{C}_{12}$ to $\mathrm{C}_{27}$ was found in trace amounts in urban stormwater runoff (16). The $C_{22}$ and $C_{31}$ ketones from the Mechelen extract could originate from plant waxes, while those encountered in Sevilla $\left(C_{14}\right.$ and $\mathrm{C}_{20}$ ) could be generated by $\beta$-oxidation of fatty acids, followed by decarboxylation or direct oxidation of hydrocarbons.

Fatty Acids. The normal fatty acid distributions in both cathedral extracts were similar, but the maxima and the CPIs $\left(n-\mathrm{C}_{22}\right.$ and 1.9 for Sevilla and $n-\mathrm{C}_{16}$ and 3.7 for Mechelen) were different. Petroleum contains only minor amounts of long-chain fatty acids; the homologues $<n-\mathrm{C}_{20}$ and probably in part $<n-\mathrm{C}_{24}$ are derived from microbial sources and the homologues $>n-\mathrm{C}_{22}$ from vascular plant waxes (14). Mazurek et al. (17) split the homologous series of fatty acids into low $\left(\mathrm{C}_{6}-\mathrm{C}_{11}\right)$, intermediate $\left(\mathrm{C}_{12}-\mathrm{C}_{19}\right)$ and high $\left(\mathrm{C}_{20}-\mathrm{C}_{33}\right)$ molecular weight acids, derived from nonspecific degradation processes (e.g., microbial metabolism, combustion, photochemical reactions, etc.), recent biogenic sources with $\mathrm{CPI}<2$ or combustion (vehicular emission) sources with CPI $>2$, and waxes. For the crust extracts, the low molecular weight acids could not be calculated because this range can hardly be distinguished from background, but the intermediate and high ranges were 1.6 and 2.1, respectively, for Sevilla and 5.8 and 4.6 for Mechelen. It is clear again that the fatty acids from Sevilla agree with vehicular emissions, whereas those of Mechelen could have a biogenic origin.

Unsaturated fatty acids (e.g., $n$ - $\mathrm{C}_{18: 1}$ ) were not detected in vehicular exhausts but were abundant in crust extracts. There were also major fatty acid components in rain and snow samples (19), derived from biogenic sources. A series of $\alpha, \omega$-dicarboxylic acids was not encountered in the extracts; only the $\mathrm{C}_{9}$ member was identified. The complex mixture of compounds contained in the extract probably prevents a more detailed identification. The $\mathrm{C}_{6}-\mathrm{C}_{18}$ range has been found as oxidation products of insoluble cell debris of algae and bacteria.

Polycyclic Aromatic Hydrocarbons (PAHs). PAHs are ubiquitous in the environment. They have been encountered in atmospheric aerosols, as well as in waters, soils, and sediments. The PAH mixtures in crust extracts are composed of unsubstituted ring systems ranging from $\mathrm{C}_{10}$ (naphthalene) to $\mathrm{C}_{20}$ (benzopyrene). The dominant analogues fluoranthene, pyrene, benzanthracene, and benzofluoranthene in vehicular exhaust (15) are also present. These unsubstituted analogues are always the predominant species in aerosols. In addition, five-membered alicyclic ring compounds (fluorene, fluoranthene, benzofluoranthene, etc.) have been considered as characteristic for a high-temperature origin of these hydrocarbons. Alkyl PAHs, also represented in the Sevilla extract, are produced in diesel engine exhaust and reflect partial re-forming of petroleum compounds at relatively low temperatures (15).

A number of aromatic ketones, including fluorenone, anthracenone, benzofluorenone, benzoanthracenone, and benzoanthracenedione, were identified. Similar compounds are characteristic molecular markers for diesel and automobile exhausts, and they are present in the extractable organic matter in urban stormwater runoff (16) and in a tar coating on the walls of a Dutch church (8). These compounds most probably originate from photochemical oxidation of precursor PAHs. In addition, S-containing PAHs (dihydrobenzothiophene and benzonaphthothiophene) were identified.

Benzene Derivatives. The presence of alkylbenzenes and alkylmethylbenzenes is highly suggestive of a pyrolytic origin. This series of compounds has barely been reported in aerosols, although they were was recently encountered in diesel soot extracts and charred bushes (19). Dialkyl phthalates are ubiquitous products used as plasticizers and are widely distributed in the environment.

A number of benzene derivatives with oxygen-containing functional groups have been identified in the crust extracts. Among them, the series of benzaldehyde, benzeneacetaldehyde, benzenemethanol, and benzoic acid is most remarkable. More complex ketones, acids, esters, and chlorine derivatives were also identified. These compounds are expected to be found in urban/industrial polluted atmospheres.

Diterpenoids. These compounds are regarded as characteristic molecular markers for conifer woods (methyl dehydroabietate and methyl 13-isopropyl-5 $\alpha$-podocarpa6,8,11,13-tetraen-16-oate), and retene is an incomplete combustion product of compounds with the abietane skeleton. They are expected in cities in which residential wood combustion is widely used, which is not the case in Sevilla. However, after a careful screening, these compounds were found, but only at trace levels.

Tricyclic Terpanes. $\mathrm{AC}_{23}$ tricyclic terpane was identified in the Sevilla extract. However, in the pyrolysate of the same cathedral, a complete suite of $\mathrm{C}_{23}-\mathrm{C}_{29}$ tricyclic terpanes was encountered (20). This indicates that the series is present in the crust but was not evidenced due to the complex mixture of unresolved compounds or hump masking to some extent the series of compounds.

Steranes. 24-Ethylcholestane, derived from sterols, widely distributed in plant and microorganisms, represents diagenetic compounds in fossil fuels. This and similar compounds were identified in the pyrolysate of the black crust from Sevilla (11).

Triterpanes. The triterpanes encountered in the crust extracts have the same $17 \alpha(H), 21 \beta(H)$-hopane distribution as petroleum residues. The hopanes are relatively easy to detect using ion monitoring at $m / z 191$, one of the major fragment ions. These compounds, present in both extracts, are widely distributed in urban aerosols, originating from lubricating oil in vehicular emissions. The pattern observed in the black crust extracts is similar to those reported for crude oil (21) and automobile and diesel engine exhausts (15).

\section{Discussion}

Origin of Elements. Several major and minor elements found in the crusts are also present in minerals in the underlying stone. Weathering of calcite provides $\mathrm{Ca}$ for gypsum. Amounts of Sr, present in aragonite lattices, may be released during weathering. The crusts are all enriched in $\mathrm{Fe}$. Leysen et al. (5) described the occurrence of a rim of iron oxides at the base of gypsum crusts on Balegem stone in Mechelen. Such rims may be formed during oxidation of $\mathrm{Fe}$ from ferroan calcite. However, particles of oxidized minerals in the crust may also be of external origin. In building stones from Sevilla, glauconite is absent, and the crust is enriched in K compared to the stone. In Balegem stone in Mechelen, the amount of $\mathrm{K}$ in the stone exceeds 
the concentration in the crust, because of the presence of glauconite. Concentrations of $\mathrm{K}$ in crusts on Euville stone are comparable to those in crusts on Balegem stone. Glauconite grains observed in Massangis stone from Mechelen may come from external sources, as this mineral is present in the neighborhood of the city; a glauconiterich (25\%) sand deposit is exposed in clay pits $10 \mathrm{~km}$ northwest of it. Hence, it must be concluded that most of the $K$ in the crust in Mechelen and Sevilla is of external origin. The same arguments are valid for quartz and feldspar as sources of $\mathrm{Si}$ and $\mathrm{Na}$. The contribution from the stone is probably negligible compared to external supply. Fly ash particles may be considered as an important source of heavy metals. In black crusts, fly ash is easily identified as spherical particles by means of EPXMA.

Evolution of Limestone Weathering. Different patterns of stone weathering were observed. Calcarenitic limestone from Sevilla and Euville limestone used in Mechelen show similar granular structures, as both rocks consist of allochems, up to $2 \mathrm{~mm}$ across, while intergranular space is not completely filled with cement. However, individual grains in Euville limestone and their epitaxial cement rim consist of only one crystal, while fossils in the limestone from Sevilla are polycrystalline and cemented by sparite. Monocrystalline grains in Euville limestone are marked by cleavage surfaces, along which cracks may be formed. Their weakening effect may be enhanced by the porous structure of the stone, as grain-to-grain contacts bear the whole pressure exerted on the stone. Ruptures along cleavage surfaces extend over several grains. Crystallization of gypsum in these cracks may widen them and cause further damage.

In Balegem limestone, gypsum crystallizes within the microsparite cement and breaks up the structure. Crystal growth starts secondary pores between glauconite or quartz grains and the calcite cement. Finally, continuous gypsum layers also develop in this stone. Similar destruction of sparite cement due to intergranular gypsum growth was also observed in calcarenites from Sevilla.

Early stages of weathering were observed in Massangis stone in Mechelen. The outermost part of the limestone is broken up into individual calcite grains. Then, a gypsum crust is developed, filling irregularities in the stone surface. Particles of external origin are trapped in the crust. During prolonged exposure of a crust surface, such particles are concentrated at its outer surface. A next generation of gypsum may be deposited, consisting of separated mushroom-like structures, often with clear large crystals or as a continuous layer. Earlier limits of gypsum growth are preserved by concentrations of particles. Dissolution of older parts of gypsum crusts is not frequently observed.

Organic Compounds. The presence of geologically mature compounds such as the tricyclic terpanes, triterpanes, steranes, and the isoprenoid hydrocarbons pristane and phytane, all characteristic molecular markers of petroleum in the black crusts, indicate a direct input of traffic-derived combustion products on the cathedral limestones. In addition, the homologous series of $n$-alkanes with the CPI near 1 points to a petrogenic origin for these hydrocarbons.

On the other hand, the identification of the series of fatty acids is indicative for a biogenic origin for some of these compounds, at least in the Mechelen cathedral. A plant origin for the high molecular weight fatty acid cannot be discarded, as the $\mathrm{C}_{24}-\mathrm{C}_{39}$ members are diagnostic molecular markers for vascular plant waxes. Some of the compounds extracted from the Sevilla crusts, as suggested by the presence of 7-methylheptadecane, are characteristic molecular markers of cyanobacteria. In fact, after a careful search, Phormidium sp. was identified in some cryptoendolithic niches, growing beneath the black crust at the gypsum-calcite interface ( 8 ).

PAHs are usually related to a pyrolytic origin, such as the combustion of fossil fuel. Sulfur heterocyclic aromatic hydrocarbons can be used as additional markers for the origin of the identified compounds. In fact, benzonaphthothiophene is characteristic of coal combustion, and it is not present within detectable levels in exhaust from gasoline engines (22). This agrees with their presence in the Mechelen crusts but not in Sevilla crusts, because coal combustion is very rare in Sevilla.

\section{Conclusions}

In different limestone types, evolution of deterioration is largely influenced by petrographic characteristics of the stone. Gypsum crusts from Mechelen and Sevilla also show variable textures, even on the same stone type. No characteristic texture for each building was observed, except that crusts from Sevilla contain more cryptocrystalline, nearly isotropic gypsum.

Sulfatation of calcite provides Ca for gypsum crusts. Except for a part of the $\mathrm{Sr}$ and Fe fraction in the crust, all other elements may be of external origin. Concentrations of elements are more or less comparable in crusts from Mechelen and Sevilla. External particles consist of fly ash, carrying heavy metals $(\mathrm{Cu}, \mathrm{Zn}, \mathrm{Pb}, \mathrm{Ba}, \mathrm{Sr}, \mathrm{Fe})$ from quartz, clay, and glauconite.

The organic compounds present in the black crust of both monuments have varied origins. Inputs of anthropogenic compounds are predominant, including those from combustion of petroleum, coal, and wood, with a comparatively minor input of cuticular waxes of higher plants.

\section{Acknowledgments}

This work was supported by the Commission of the European Community, Project STEP-CT90-0107.

\section{Literature Cited}

(1) Falcon, T. La catedral de Sevilla; Grafitalica: Sevilla, 1980.

(2) Saiz-Jimenez, C.; Bernier, F. 6th Triennial Meeting, ICOM Committee for Conservation, Ottawa, Canada, 1981; paper 81 / $10 / 5$.

(3) Esbert, R. M.; Ordaz, J.; Alonso, F. J.; Ruiz de Argandoña, V. G.; Montoto, M.; Marcos, R.; Valdeon, L. Mater. Constr. 1988, 38, 5-23.

(4) Leysen, L.; Roekens, E.; Komy, Z.; Van Grieken, R. Anal. Chim. Acta 1987, 195, 247-255.

(5) Leysen, L.; Roekens, E.; Van Grieken, R. Sci. Total Environ. 1989, $78,263-287$.

(6) Evamy, B. Sedimentology 1963, 2, 164-170.

(7) Xhoffer, C.; Bernard, P.; Van Grieken, R.; Van der Auwera, A. Environ. Sci. Technol. 1991, 25, 1470-1478.

(8) Saiz-Jimenez, C.; Hermosin, B.; Ortega-Calvo, J. J.; GomezAlarcon, G. J. Anal. Appl. Pyrol. 1991, 20, 239-251.

(9) Goldschmidt, V. Geochemistry, Oxford At The Clarendon Press: Oxford, 1954.

(10) Geets, S.; De Breuck, W.; Jacobs, P. Natuurwet. Tijdschr. 1985, $67,3-25$

(11) Saiz-Jimenez, C. Atmos. Environ. 1993, 27B, 77-85.

(12) Saiz-Jimenez, C. In Science, Technology and European Cultural Heritage; Baer, N. S., Sabbioni, C., Sors A. I., Eds.; CECButterworth-Heinemann: Oxford, 1991, pp 523-526.

(13) Del Rio, J. C.; Philp. R. P.; Allen, J. Org. Geochem. 1992, 18, 541553.

(14) Simoneit, B. R. T. Int. J. Environ. Anal. Chem. 1986, 23, 207-237.

(15) Simoneit, B. R. T. Int. J. Environ. Anal. Chem. 1985, 22, 203-233. 
(16) Eganhouse, R. P.; Simoneit, B. R. T.; Kaplan, I. R. Environ. Sci. Technol. 1981, 15, 315-326.

(17) Mazurek, M. A.; Cass, G. R.; Simoneit, B. R. T. Environ. Sci. Technol. 1991, 25, 684-694.

(18) Kawamura, K.; Kaplan, I. R. Atmos. Environ. 1986, 20, 115-124.

(19) Saiz-Jimenez, C. In Humic Substances in the Global Environment and Implications in Human Health; Senesi, N., Miano T. M., Eds.; Elsevier: Amsterdam, in press.

(20) Saiz-Jimenez, C.; Garcia del Cura, M. A. In Science, Technology and European Cultural Heritage; Baer, N. S., Sabbioni, C., Sors A. I., Eds.; CEC-Butterworth-Heinemann: Oxford, 1991; pp 527530.

(21) Philp, R. P. Mass Spectrom. Rev. 1985, 4, 1-54.
(22) Grimmer, G.; Naujack, K. W.; Schneider, D. In Polycyclic Aromatic Hydrocarbons: Chemistry and Biological Effects; Bjorseth, A., Dennis, A. J., Eds.; Battelle Press: Columbus, OH, 1980, 107125.

Received for review February 1, 1995. Accepted March 10, $1995 .^{\circ}$

ES9401712

${ }^{\otimes}$ Abstract published in Advance ACS Abstracts, April 15, 1995. 